\title{
Liechtenstein: Assessment of the Supervision and Regulation of the Financial Sector Technical Note on the Basel Core Principles and IOSCO Securities
}

This Assessment of Financial Sector Supervision and Regulation containg a technical note on the Basel Core Principles and IOSCO Securities was prepared by a staff team of the International Monetary Fund. It is based on the information available at the time it was completed in April 2008. The views expressed in this document are those of the staff team and do not necessarily reflect the views of the government of Liechtenstein or the Executive Board of the IMF.

The policy of publication of staff reports and other documents by the IMF allows for the deletion of market-sensitive information.

Copies of this report are available to the public from International Monetary Fund $\bullet$ Publication Services 700 19th Street, N.W. • Washington, D.C. 20431 Telephone: (202) 623-7430 • Telefax: (202) 623-7201

E-mail: publications@imf.org • Internet: http://www.imf.org

Price: $\$ 18.00$ a copy

\section{International Monetary Fund Washington, D.C.}



OFFSHORE FinANCIAL CENTER ASSESSMENT PROGRAM

LIECHTENSTEIN

Module 2 AsSessment

FOCUSED REVIEW OF THE:

Basel Core Principles for Effective BANKING SUPERVISION

AND

IOSCO ObJeCtives AND PRINCIPLes OF SECURITIES REgULATION

TECHNICAL NOTE

APRIL 2008

INTERNATIONAL MONETARY FUND

MONETARY AND CAPITAL MARKET S DEPARTMENT 


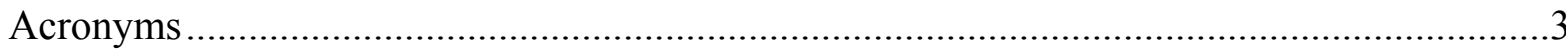

I. Basel Core Principles for Effective Banking Supervision.....................................................

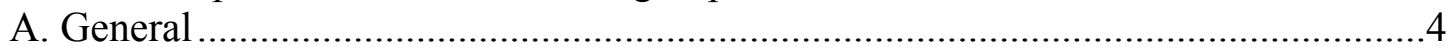

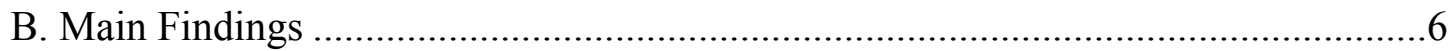

C. Principle by Principle Review ...........................................................................

D. Recommended Actions and Authorities' Response to the Focused Review ..........12

II. IOSCO Objectives and Principles of Securities Regulation .............................................14

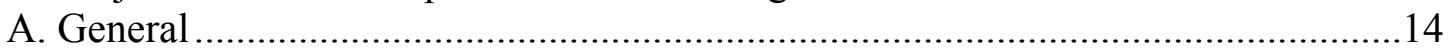

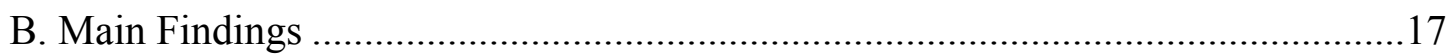

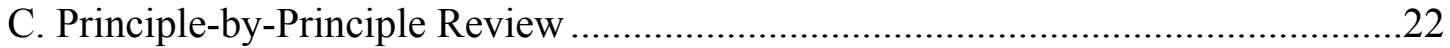

D. Recommended Actions and Authorities' Response to the Focused Review ..........29

Tables

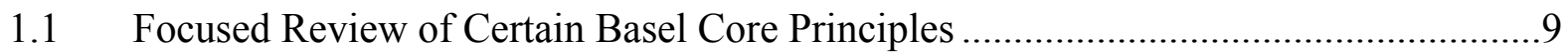

1.2 Summary of Implementation of the Basel Core Principles ........................................12

1.3 Action Plan to Improve Implementation of the Basel Core Principles.........................12

1.4 Status of Recommendations from the 2002 Action Plan: Basel Core .........................13

$2.1 \quad$ Focused Review of Certain IOSCO Principles........................................................22

2.2 Summary of Implementation of the IOSCO Principles ...............................................2

2.3 Action Plan to Improve Implementation of the IOSCO Principles .............................29

2.4 Status of Recommendations from the 2002 Action Plan: IOSCO Principles...............30 


\section{ACRONYMS}

$\mathrm{BCP}$

CESR

CHF

CRD

EEA

$\mathrm{EU}$

FMA

FSA

IOSCO

$\mathrm{MCM}$

MiFID

MOU

OFC

ROSC

UCITS
Basel Core Principles for Effective Banking Supervision

Committee of European Securities Regulators

Swiss franc

Capital Requirement Directive (implementation of Basel II)

European Economic Area

European Union

Financial Markets Authority

Financial Services Authority

International Organization of Securities Commissions

IMF Monetary and Capital Markets Department

Markets in Financial Instruments Directive

Memorandum of Understanding

Offshore Financial Center

Report on Observance of Standards and Codes

Undertakings for collective investments in transferable securities (investment funds, mutual funds) 


\section{Basel Core Principles for Effective Banking Supervision}

A. General

1. A focused review of observance of the Basel Core Principles for Effective Banking Supervision (Basel Core Principles) was conducted as part of the offshore financial center assessment in the Principality of Liechtenstein. ${ }^{1}$ This focused review is a follow-up to the assessment of 2002 (the 2002 Assessment) and deals only with those Principles that were rated "materially noncompliant" during that assessment. ${ }^{2}$

\section{Institutional and macroprudential setting, market structure overview}

2. The Financial Market Authority (FMA), which came into operation on January 1,2005 , is the single regulatory authority for the financial sector and replaces the Financial Services Authority (FSA). On the banking side, it is responsible for the authorization, ongoing supervision, and revocation of banks. Ongoing supervision is shared with the banks' external auditors, who are also authorized by the FMA. Under law, the external auditors are required to undertake an annual prudential inspection of each bank on behalf of the FMA and report to it on their findings. The FMA may also carry out inspections.

3. Liechtenstein has a GDP of US\$5.2 billion, of which 40 percent comes from industry and 30 percent from financial services. The employed population is 30,000 , of which 14,500 are commuters from outside Liechtenstein. There are 35,000 residents, including 12,000 foreigners.

4. Currently, 15 banks operate in Liechtenstein (one additional bank is in the process of being wound down without loss to the depositors). In 2002, at the time of the previous assessment, two finance companies also operated in Liechtenstein; both have since been liquidated with the result that no finance companies operate currently. ${ }^{3}$

5. The market is highly concentrated with the three largest banks accounting for 90 percent of the total banking balance sheet size; 86 percent of assets under management; 89 percent of operating profits before tax, and 63 percent of employment in the banking sector. The main activity of all of the banks is asset management (private

\footnotetext{
${ }^{1}$ The focused review was conducted by Mr. Michael Deasy (consultant to the Fund from the Financial Regulator in Ireland).

${ }^{2}$ Under current IMF policies, partial assessments of financial sector standards (e.g., BCP and IOSCO) do not result in issuance of a formal Report of Observance of Standards and Codes.

${ }^{3}$ Finance companies - which were supervised by the FSA and now would fall to the FMA — are permitted to engage in general banking business with the exception of deposit-taking.
} 
banking); only the three largest banks conduct retail and corporate business. Lending largely comprises mortgage and Lombard loans.

6. At end-2006, the balance sheet size of the 15 banks amounted to US\$38 billion and client assets under management to US\$139 billion. All banks report high capital ratios (the average consolidated ratio is 17.5 percent) and all, with the exception of one, which broke even, reported profits for 2006.

7. Two of the three largest banks are publicly quoted on the Swiss Stock Exchange_LLB Bank and VP Bank. The third — LGT — was once listed but is now privately owned by the family of the Prince of Liechtenstein. Four banks are subsidiaries of Austrian banks and three are subsidiaries of Swiss banks. Eight banks, including the three largest, are owned wholly, or in part, by Liechtenstein interests. Only the largest three banks have operations abroad. LGT has six banking subsidiaries - in Austria, Cayman Islands, Germany, Ireland, Singapore, and Switzerland. It also has six branches in Germany and three branches in Switzerland. VP Bank has subsidiary banks in the British Virgin Islands, Germany, and Luxembourg, and is in the process of establishing a merchant bank in Singapore. It also has an asset management company in Germany. LLB has two banking subsidiaries and three branches in Switzerland.

8. As a member of the European Economic Area (EEA) since 1995, Liechtenstein is obliged to transpose EU law into national legislation. Accordingly, all its regulatory legislation - including the implementation of the EU Capital Requirement Directive (which governs implementation of Basel II) — is based on the relevant EU Directives (see below under Main Findings regarding the implementation in Liechtenstein of Basel II).

9. Liechtenstein has close ties also with the Swiss financial system. The Swiss franc is the official currency and the Swiss Central Bank acts as lender of last resort. Further links include the stock exchange and interbank clearing. The external auditors to the banks are largely based in Switzerland, as are many employees in the financial sector.

10. The Liechtenstein Bankers Association is active, employing six full-time staff. As part of its supportive role to the banking system, it manages a deposit and investment protection scheme based on the corresponding EU Directives. Losses of up to $€ 20,000$ in each of the deposit and security areas are covered, subject to a maximum payout of CHF 300 million.

\section{Information and methodology used for the focused review}

\section{This focused review of compliance with the Core Principles has been made on a} qualitative basis. The focused review used the 1998 methodology. Four ratings are used: compliant, largely compliant, materially noncompliant, and noncompliant. To achieve a "compliant" rating with a Principle, all "essential" criteria generally must be met without any significant deficiencies. 
12. There may be instances where a country can demonstrate that a Principle has been achieved through different means. Conversely, due to specific conditions in individual countries, the essential criteria may not always be sufficient to achieve the objective of the Principle, and therefore, one or more additional criteria and/or other measures may also be deemed necessary by the assessor to judge that compliance is achieved. A "largely compliant" rating is given if only minor shortcomings are observed, and these as sufficient to raise serious doubts about the authority's ability to achieve the objective of that Principle.

13. A "materially noncompliant rating" is given when the shortcoming is sufficient to raise doubts about the authority's ability to achieve compliance, but substantive progress has been made. A "noncompliant" rating is given when no substantive progress toward compliance has been achieved or when insufficient information was available to allow a reliable determination that substantive progress had been made toward compliance. "Not applicable" is rendered for a Principle deemed by the assessors to not have relevance.

\section{The focused review has been conducted in Liechtenstein under the OFC} assessment program. It was carried out on the basis of the following laws: Law on Banks and Finance Companies (Banking Act) 1992 as amended; the Banking Ordinance 1994, as amended and which elaborated upon the Banking Act; the Financial Market Authority Act, which established the FMA, the Asset Management Act, which transposed the EU Markets in Financial Instrument Directive (MiFID) and the Capital Requirement Ordinance 2006, which transposed the EU Capital Requirement Directive into Liechtenstein law.

15. The assessor held working sessions with the relevant staff of the FMA, the Bankers Association, the Auditors Association, the Asset Managers Association, as well as with a number of commercial banks, asset managers, and external auditors. The assessor was provided with whatever information was required.

\section{General preconditions for effective banking supervision}

16. The banking system operates in a small but highly developed economy. Insofar as could be judged, international standards and best practices are observed by all participants.

\section{B. Main Findings}

17. The focused review concentrated on those Principles that were rated at "materially noncompliant" or lower during the 2002 Assessment. There were five Principles that received such ratings - all rated as materially noncompliant. Four related to lack of resources within the regulator and the fifth to lack of guidance on operational and legal risk management. There have been very substantial improvements in all cases.

Principle 1(2). Each supervisory agency should possess operational independence and adequate resources. 
18. The serious level of understaffing that existed in 2002 appears to have been addressed. Five professional staff with relevant experience have been recruited and two more have recently signed contracts to commence work. This, together with the inspection work carried out by external auditors, would currently appear to be appropriate to supervise adequately the 15 banks. In order to sustain the adequate staffing with respect to the banking supervision, in particular, under the prospective regime of Basel II and MiFID, the resources should be reviewed.

Principle 13. Management by banks of operational, legal, and reputational risks

19. Lack of guidelines by the regulator in these areas was identified as a serious shortcoming in the $\mathbf{2 0 0 2}$ assessment. This has since been addressed by inclusion in the Banking Ordinance and the Capital Requirement Ordinance of appropriate guidelines. In addition, the external auditor is required to describe and comment upon how each bank manages these risks in his annual report to the FMA.

Principle 16. Onsite and offsite supervision

20. The additional staff resources provide for more effective onsite and offsite supervision. It facilitates a proper analysis of bank returns and a more critical assessment of the external auditors' inspection reports. It has also facilitated the FMA's being able to carry out its own on-site inspections.

\section{Principle 17. Bank management contact}

21. Both formal and informal meetings and communications take place as needed. The FMA's knowledge of the banks has allowed it to develop a risk-rating approach to the supervision of the banks.

\section{Principle 18. Offsite supervision}

22. The prudential reports that the FMA receives are in keeping with international practice and it has the resources to analyze these in meaningful manner.

New Basel Core Principles and Implementation of Basel II

23. Based on a limited review, the FMA would do generally well in meeting the requirements for compliance, particularly in the context of compliance with the requirements of Basel II. In conjunction with the focused review of the Core Principles considered materially noncompliant at the 2002 mission, a limited review also considered the level of general compliance with the revised Basel Core Principles, which were approved in 2006. The Principles deal to a large extent with enhanced risk management processes and include specific principles to deal with liquidity and interest rate risk. Basel II is also very 
much concerned with increased risk management and has specific sections dealing with liquidity and interest rate risk.

24. The implementation of Basel II by Liechtenstein entails the transposition of the EU Capital Requirement Directive (CRD) into law and its subsequent application. The CRD and Basel II are similar in all material respects; any differences generally arise from the fact that all banks (and investment companies) in the EU are statutorily obliged to implement the CRD, whereas no such statutory obligation attaches to Basel II.

25. The transposition of the CRD entailed the drafting of a new ordinance (Capital Requirement Ordinance-CRO-which runs to over 400 pages) and minor amendments to the Banking Act. The CRO was passed in December 2006 and became effective from January 1, 2007. Formal application of the new regime will commence on January 1, 2008.

26. To assist in the drafting of the CRO, the FMA employed two consultants, a Liechtenstein EU expert and a Swiss lawyer with banking experience. Two separate consultations were held with the industry with respective closing dates of February 2006 and May 2006. Workshops were also held with industry and external auditors. The FMA has also updated its website, giving details of the legislative changes, details of the discretions allowed, and a question-and-answer section. It has also signed employment contracts with two persons, one of whom has IT experience in verifying internal models, to assist in monitoring compliance by banks with the CRD.

27. The banks that were interviewed during the course of the focused review (including the three largest) appeared fully aware of the importance of Basel II. All indicated that they had established project teams to prepare for its introduction. All 15 banks are adopting the standardized approach for both credit risks and the basis indicator approach for operational risk. This approach is influenced by the relatively uncomplicated nature of banking business in Liechtenstein, i.e., private banking and small and straight-forward lending practices.

\section{Markets in Financial Instruments Directive}

28. As a member of the EEA, Liechtenstein is also implementing the MiFID, which comes into effect in November 2007. MiFID will be implemented via the Asset Management Act and changes to the Banking Act. The detailed provisions of the MiFID are currently in the course of a consultation process with the industry. The outcome of the consultation process will be reflected in a new ordinance. It may also result in minor changes to the Asset Management Act.

29. The MiFID will have limited impact on Liechtenstein, given the absence of a stock exchange. However, it will apply to investment/asset management companies and banks that engage in such activities. Its aim is to encourage a single investment-services 


\section{Principle by Principle Review}

\section{Table 1.1 Focused Review of Certain Basel Core Principles}

\begin{tabular}{|c|c|}
\hline Principle 1. & $\begin{array}{l}\text { Objectives, Autonomy, Powers, and Resources } \\
\text { An effective system of banking supervision will have clear responsibilities and objectives } \\
\text { for each agency involved in the supervision of banks. Each such agency should possess } \\
\text { operational independence and adequate resources. A suitable legal framework for banking } \\
\text { supervision is also necessary, including provisions relating to the authorization of banking } \\
\text { establishments and their ongoing supervision; powers to address compliance with laws, as } \\
\text { well as safety and soundness concerns; and legal protection for supervisors. Arrangements } \\
\text { for sharing information between supervisors and protecting the confidentiality of such } \\
\text { information should be in place. }\end{array}$ \\
\hline Principle 1(2) & Each such agency should possess operational independence and adequate resources. \\
\hline Description & $\begin{array}{l}\text { The governing structure of the FMA is dealt with in the FMA Act - Articles } 3 \text { to } 10 \text {. Article } 3 \\
\text { states that the FMA shall be independent in the exercise of its activities and shall not be bound } \\
\text { by any instructions. Article } 7 \text { provides for the composition of the Board which shall comprise } \\
5 \text { persons - the chairman, deputy chairman and three other members. It also states that } \\
\text { members cannot serve in the government, parliament or a court. In addition, the chairman, } \\
\text { deputy chairman and at least one other member cannot be a director, employee or a ten } \\
\text { percent plus shareholder in any regulated entity. Members of the Board are appointed for a } \\
\text { five year term, subject to renewal. Terminations can only occur for normal stated reasons e.g., } \\
\text { conclusion of term of office, resignation, criminal offence that would impair performance of } \\
\text { the office. } \\
\text { The Board must adopt and submit an annual report to parliament. } \\
\text { Excluding the head of the Banking and Securities Department, the Banking Supervision } \\
\text { Division (BSD) is staffed by five professionals with university degrees, one trainee with a } \\
\text { university degree and one administrative assistant. Almost all of the senior staff have } \\
\text { previously worked in the wider financial sector, including commercial banks and accountancy } \\
\text { firms. Two additional staff have been recruited, both to assist in assessing the implementation } \\
\text { by the banks of Basel II. } \\
\text { The staff interviewed during the course of the mission displayed an impressive degree of } \\
\text { expertise and knowledge, particularly in relation to the transposition into Liechtenstein law } \\
\text { and subsequent implementation of the EU Capital Requirement Directive (i.e. Basel II in EU } \\
\text { terms) and the MiFID - both of which and particularly Basel II - will have a significant impact } \\
\text { on banking supervision and banking business in the future. } \\
\text { The FMA is also assisted in its supervisory role by the fact that the banks' external auditors } \\
\text { carry out prudential inspections (in addition to their statutory audit obligations) of the banks } \\
\text { on an annual basis (see Principle 16). } \\
\text { The banks and other parties that were interviewed during the course of the focused review } \\
\text { commented very favorably on the competence and professionalism of the banking supervision } \\
\text { division }\end{array}$ \\
\hline
\end{tabular}




\begin{tabular}{|c|c|}
\hline Assessment & Compliant \\
\hline Comments & $\begin{array}{l}\text { This Principle was rated "materially noncompliant" during the } 2002 \text { assessment on the basis } \\
\text { of insufficient resources - both in terms of numbers and expertise. The current situation } \\
\text { represents a huge improvement over } 2002 \text {. } \\
\text { The FMA should keep its resources, both in terms of numbers and expertise, under review, } \\
\text { particularly in the light of increasing regulatory requirements emanating from the EU. }\end{array}$ \\
\hline Principle 13. & $\begin{array}{l}\text { Other Risks } \\
\text { Banking supervisors must be satisfied that banks have in place a comprehensive risk } \\
\text { management process (including appropriate Board and senior management oversight) to } \\
\text { identify, measure, monitor, and control all other material risks and, where appropriate, to } \\
\text { hold capital against these risks. }\end{array}$ \\
\hline Description & 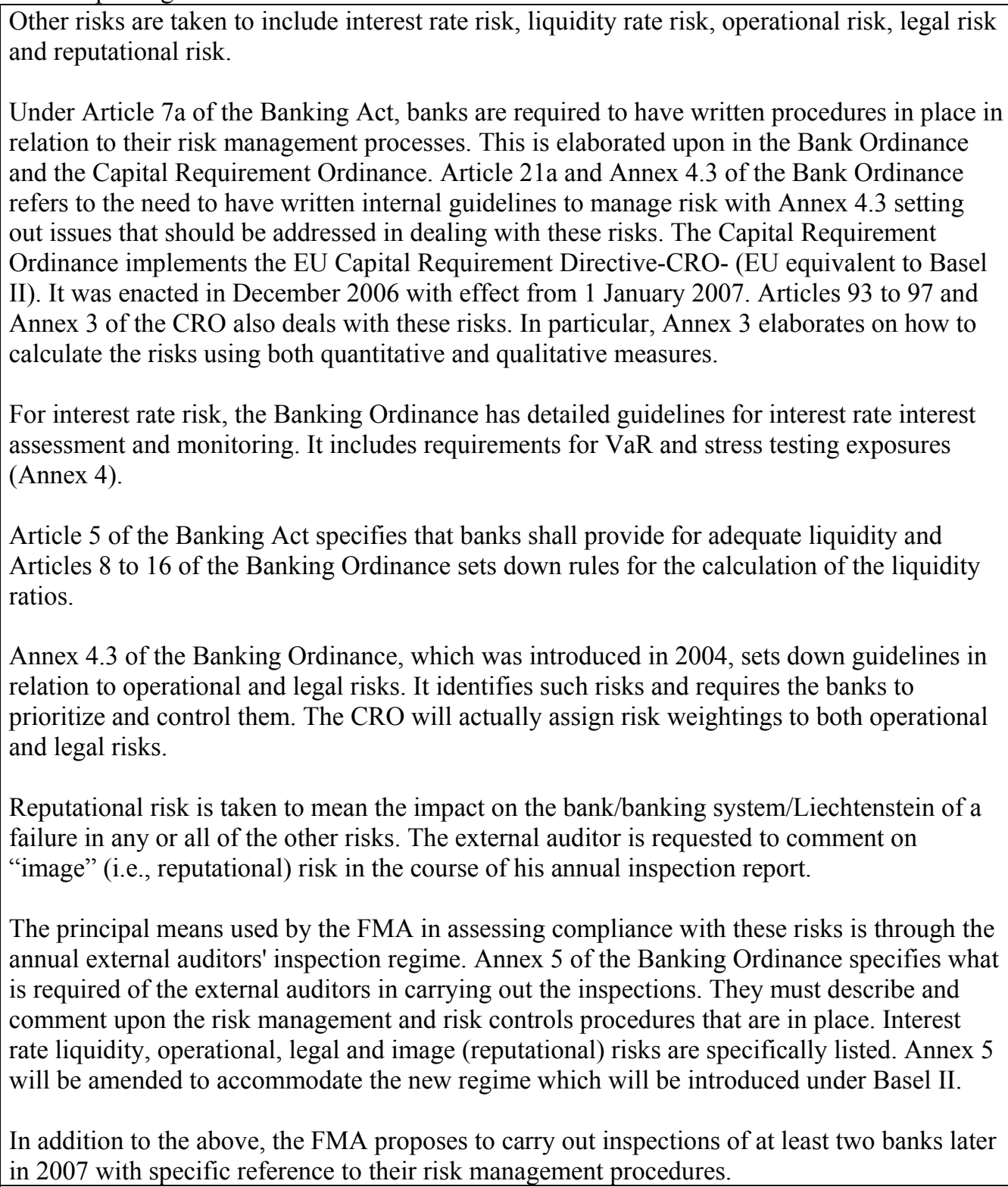 \\
\hline Assessment & Compliant \\
\hline Comments & $\begin{array}{l}\text { This Principle was rated "materially noncompliant" during the previous assessment on the } \\
\text { grounds that the regulator had not published some guidelines on operational, legal and } \\
\text { reputational risks. Such guidelines were published in Annex } 4.3 \text { of the Banking Ordinance in } \\
2004 \text { and are developed in the CRO. }\end{array}$ \\
\hline
\end{tabular}




\begin{tabular}{|c|c|}
\hline Principle 16. & $\begin{array}{l}\text { On-Site and Off-Site Supervision } \\
\text { An effective banking supervisory system should consist of some form of both on-site and } \\
\text { off-site supervision. }\end{array}$ \\
\hline Description & $\begin{array}{l}\text { The FMA employs a dual system for the purposes of on-site inspection. The main on-site } \\
\text { inspection regime is carried out by the external auditors who are obliged by statute to carry } \\
\text { out inspections of each bank on an annual basis. (Article } 11 \text { of the Banking Act) To assist the } \\
\text { external auditors in carrying out this function the FMA has drawn up a template (Annex } 5 \text { of } \\
\text { the Banking Ordinance) listing the issues they would wish the external auditors to comment } \\
\text { upon. This is a detailed listing covering, inter alia, compliance with licensing requirements } \\
\text { (e.g., capital, liquidity, and large exposures), risk management and risk control, anti-money } \\
\text { laundering requirements, consolidated supervision, etc. The external auditors must also audit, } \\
\text { on a sample basis, the various reports which the banks must submit to the FMA. } \\
\text { The external auditors are required to report on their findings to the FMA by the end of June } \\
\text { (all the banks have a December year end) unless they uncover an issue of serious concern, in } \\
\text { which case they must report to the FMA as a matter of urgency. The banking supervision } \\
\text { division, having clarified any outstanding issues with the external auditors, meet with the } \\
\text { management of each bank to discuss the findings. } \\
\text { The banking supervision division holds workshops with the external auditors from time to } \\
\text { time with a view to elaborating on its template and advising on its requirements in this area. } \\
\text { Apart from this, the FMA is the licensing authority for auditors and it sets down additional } \\
\text { requirements for those auditors involved in the supervision of banks and other financial } \\
\text { institutions. } \\
\text { The FMA also carries out its own inspection regime. In } 2006 \text {, it carried out two prudential } \\
\text { inspections - these were in response to issues that arose in the two banks in questions. It } \\
\text { proposes to become involved in theme based inspections in the future. For instance, it has } \\
\text { plans to carry out inspections of the risk management processes in at least two banks later in } \\
2007 \text {. } \\
\text { On off-site supervision, the FMA receives and examines the standard returns from banks (e.g., } \\
\text { capital adequacy on a quarterly basis; large exposures, liquidity on a monthly basis; } \\
\text { consolidated data and six monthly accounts on a half yearly basis; annual accounts on an } \\
\text { annual basis) }\end{array}$ \\
\hline Assessment & Compliant \\
\hline Comments & $\begin{array}{l}\text { This Principle was rated "materially noncompliant" during the } 2002 \text { assessment the Banking } \\
\text { Supervision Department had insufficient staff and expertise to carry out a meaningful analysis } \\
\text { of either the inspection reports submitted by the external auditors or the periodic reports } \\
\text { submitted by the banks. }\end{array}$ \\
\hline Principle 17. & $\begin{array}{l}\text { Bank Management Contact } \\
\text { Banking supervisors must have regular contact with bank management and a thorough } \\
\text { understanding of the institution's operations. }\end{array}$ \\
\hline Description & $\begin{array}{l}\text { The FMA has regular contact with each of the } 15 \text { banks, both on a formal and ad-hoc basis. } \\
\text { The formal meetings take place in the context of the FMA's review of the external auditors' } \\
\text { annual inspection reports. Following consideration of these reports by the FMA, it meets the } \\
\text { Board and senior executives as well as the respective experts of each bank to discuss the } \\
\text { findings and prompt measures. As the external auditors are required to submit their reports by } \\
\text { the end of June each year (all the banks have a financial year end of December), the FMA } \\
\text { meetings with the bank Boards take place in the third and fourth quarters of the year. Ad-hoc } \\
\text { meetings and other communications take place as need be and as issues arise. Also, for each } \\
\text { significant initiative taken by the FMA (e.g., Basel II, MiFID), it engages in an extensive } \\
\text { consultation process with the banks. } \\
\text { As an indication of the FMA's understanding of the operations of the banks, it has devised a } \\
\text { risk rating assessment of them. This assessment is based on both quantitative and qualitative }\end{array}$ \\
\hline
\end{tabular}




\begin{tabular}{|c|c|}
\hline & $\begin{array}{l}\text { measures and takes into account such issues as the eternal auditors' reports, the various } \\
\text { prudential reports submitted by the banks, press monitoring, general interaction with the } \\
\text { banks and further plans by the banks (e.g., strategy, establishing activities in another } \\
\text { jurisdiction). }\end{array}$ \\
\hline Assessment & Compliant \\
\hline Comments & $\begin{array}{l}\text { This Principle was rated "materially noncompliant" during the } 2002 \text { assessment. Insufficient } \\
\text { staff made impossible regular contact with the banks or a thorough of their operations. }\end{array}$ \\
\hline Principle 18. & $\begin{array}{l}\text { Off-Site Supervision } \\
\text { Banking supervisors must have a means of collecting, reviewing, and analyzing prudential } \\
\text { reports and statistical returns from banks on a solo and consolidated basis. }\end{array}$ \\
\hline Description & $\begin{array}{l}\text { The FMA receives the following returns which would be regarded as adequate to meet off-site } \\
\text { supervisory requirements: quarterly capital adequacy requirements; monthly analysis reports } \\
\text { on own funds, large exposures, liquidity; six monthly reports on consolidated capital } \\
\text { adequacy and on large exposures and annual reports. } \\
\text { The FMA has the necessary expertise to analyze these and does so. }\end{array}$ \\
\hline Assessment & Compliant \\
\hline Comments & $\begin{array}{l}\text { This Principle was rated as "materially noncompliant" during the } 2002 \text { assessment due do lack } \\
\text { of resources }\end{array}$ \\
\hline
\end{tabular}

Table 1.2 Summary of Implementation of the Basel Core Principles

\begin{tabular}{|l|c|c|c|c|c|}
\hline \multicolumn{1}{|c|}{ Core Principle } & $\mathbf{C}^{\mathbf{l}}$ & $\mathbf{L C}^{\underline{\mathbf{2}}}$ & $\mathbf{M N C}^{\underline{\mathbf{3}}}$ & $\mathbf{N C}^{\underline{\mathbf{4}}}$ & $\mathbf{N A}^{\underline{\mathbf{5}}}$ \\
\hline 1. Objectives, Autonomy, Powers, and Resources & & & & & \\
\hline \multicolumn{1}{|c|}{ 1.2 Independence } & $\mathrm{x}$ & & & & \\
\hline 13. Other Risks & $\mathrm{x}$ & & & & \\
\hline 16. Onsite and Offsite Supervision & $\mathrm{x}$ & & & & \\
\hline 17. Bank Management Contact & $\mathrm{x}$ & & & & \\
\hline 18. Offsite Supervision & $\mathrm{x}$ & & & & \\
\hline
\end{tabular}

$1 /$ C: Compliant.

${ }^{2 /}$ LC: Largely compliant.

3/ MNC: Materially noncompliant.

${ }^{4 /} \mathrm{NC}$ : Noncompliant.

${ }^{5}$ NA: Not applicable.

\section{Recommended Actions and Authorities' Response to the Focused Review}

\section{Table 1.3 Action Plan to Improve Implementation of the Basel Core Principles}

\begin{tabular}{|l|l|}
\hline \multicolumn{1}{|c|}{ Reference Principle } & \multicolumn{1}{c|}{ Recommended Action } \\
\hline $\begin{array}{l}\text { Principle 1(2) - Each [supervisory] agency should } \\
\text { possess operational independence and adequate } \\
\text { resources. }\end{array}$ & $\begin{array}{l}\text { The FMA should keep its resources, both in terms of } \\
\text { numbers and expertise, under review, particularly in the } \\
\text { light of increasing regulatory requirements emanating } \\
\text { from the EU. }\end{array}$ \\
\hline
\end{tabular}


Table 1.4 Status of Recommendations from the 2002 Action Plan: Basel Core Principles

\begin{tabular}{|l|l|}
\hline \multicolumn{1}{|c|}{$\begin{array}{c}\text { Reference Principle \& 2002 Assessment } \\
\text { Recommended Action }\end{array}$} & \multicolumn{1}{c|}{ Actions Taken } \\
\hline $\begin{array}{l}\text { Independence and resources (CP 1.2) } \\
\text { Recruit experienced staff and/or train new staff }\end{array}$ & $\begin{array}{l}\text { Additional staff with experience in banking have been } \\
\text { recruited and additional training has been undertaken } \\
\text { for all staff. }\end{array}$ \\
\hline $\begin{array}{l}\text { Information sharing (CP 1.6) } \\
\text { Delimit banking secrecy with regard to supervisory } \\
\text { concerns }\end{array}$ & $\begin{array}{l}\text { A 2003 court case, coupled with statutory amendments } \\
\text { to the Banking Act, have clarified access of } \\
\text { supervisors to client-specific information. }\end{array}$ \\
\hline $\begin{array}{l}\text { Other risks (CP 13) } \\
\text { Determine applicable norms }\end{array}$ & $\begin{array}{l}\text { The Banking Ordinance was amended in 2004 to } \\
\text { provide guidelines for these risks and the Capital } \\
\text { Requirement Ordinance 2006 introduced risk } \\
\text { weightings for them. }\end{array}$ \\
\hline $\begin{array}{l}\text { Onsite and offsite supervision (CP 16) } \\
\text { Add resources for effective and comprehensive } \\
\text { analysis of audit reports and bank reporting }\end{array}$ & $\begin{array}{l}\text { Additional staff with experience in banking have been } \\
\text { recruited and additional training has been undertaken } \\
\text { for all staff. }\end{array}$ \\
\hline $\begin{array}{l}\text { Bank management contact (CP 17) } \\
\text { Add resources for effective and comprehensive } \\
\text { understanding of banks' operations }\end{array}$ & $\begin{array}{l}\text { Additional staff with experience in banking have been } \\
\text { recruited and additional training has been undertaken } \\
\text { for all staff. }\end{array}$ \\
\hline $\begin{array}{l}\text { Offsite supervision (CP 18) } \\
\text { Add resources for effective and comprehensive } \\
\text { understanding and analysis of audit and bank reports }\end{array}$ & $\begin{array}{l}\text { Additional staff with experience in banking have been } \\
\text { recruited and additional training has been undertaken } \\
\text { for all staff. }\end{array}$ \\
\hline
\end{tabular}

\section{Authorities Response}

The Financial Market Authority Liechtenstein (FMA) is very grateful to the IMF for having carried out an update of the OFC assessment 2002. Five principles have been reassessed, all of them rated "compliant." This reflects the very positive development and progress Liechtenstein has achieved in general and the FMA, in particular, since its start on January 1, 2005.

Since the assessment took place in March/April 2007, some of the recommendations have already been implemented. MiFID was implemented into national law by November 2007 and is fully applicable to banks and asset management companies. The FMA regularly held workshops with auditors of asset management companies to give them proper guidance and developed a model audit report. Thus, many of the current recommendations will be met. 


\section{IOSCO Objectives and Principles of Securities Regulation}

\section{A. General}

30. A focused review of the observance of certain IOSCO Objectives and Principles of Securities Regulation (the IOSCO Principles) was conducted as part of an update to the Offshore Center Assessment in the Principality of Liechtenstein. ${ }^{4}$ Only those principles that were assessed during the full assessment in 2002 (the 2002 Assessment) as being less than broadly implemented were reassessed. ${ }^{5}$

\section{Information and methodology used for the focused review}

31. This focused review followed the IOSCO methodology for assessing the IOSCO Principles. As in the 2002 Assessment, the limited range of securities activities in Liechtenstein was an important factor in assessing the IOSCO Principles. The financial sector is focused on private banking, with an emphasis on asset management, and this is mirrored in the activity of market intermediaries, which is limited to portfolio management, investment advice, management of collective investment schemes, and some brokerage activities. There are no active secondary markets, no underwriting activities, very few issues of securities, and no direct trading on secondary markets.

32. The focused review considered the relevant legislation, questionnaires prepared by the Financial Markets Authority (FMA) prior to the mission, detailed discussions with FMA staff, and with members of industry and industry associations. Staff of the FMA was very generous in making themselves available for discussions which that were helpful, frank, and forthcoming. Assistance from industry representatives was also extremely helpful. Much of the relevant information, such as laws and ordinances, was made available in English.

\section{Institutional and macroprudential setting, market structure overview}

33. Securities-related activities in Liechtenstein are carried out by universal banks, licensed under the Banking Act, investment undertakings (collective investment schemes) licensed under the Investment Undertakings Act, and asset managers licensed under the Asset Management Act. Banks are focused on private banking and asset management primarily for high- net- worth clients, the majority of whom are located outside of Liechtenstein (the largest number are in European jurisdictions). While only one bank is a participant of the Swiss stock exchange (SWX), all banks also offer brokerage services-

\footnotetext{
${ }^{4}$ The focused review was conducted by Tanis MacLaren (consultant to the Fund and formerly with the Ontario Securities Commission, Canada).

${ }^{5}$ Under current IMF policies, partial assessments of financial sector standards (e.g., BCP and IOSCO) do not result in issuance of a formal Report of Observance of Standards and Codes.
} 
including the sale of collective investment products, equities and bonds - to retail investors. Only banks can open this type of customer account.

34. The most notable change in the regulation of market participants since the 2002 assessment is that asset management (outside the banks) and the provision of investment advice is now carried out by companies licensed and directly supervised by the FMA under the Asset Management Act, which came into effect on January 1, 2006. While there is some recognition of the fact that trustees formerly carried on these activities, ${ }^{6}$ they now have to be carried on through a separately incorporated asset management company. Customer assets must be in custody at a third- party bank (located in Liechtenstein or elsewhere), and the asset manager has no ability to withdraw either assets or cash from those accounts. Investment undertakings are those entities that operate collective investment schemes. They may operate collective investment schemes organized as trusts or as limited liability companies. Many collective investment schemes are eligible under the UCITS III Directive for sale in other European jurisdictions.

35. As of December 31, 2006, there are 15 banks licensed and operating actively ${ }^{7}$ in Liechtenstein, all of which carry out securities activities. There are 28 licensed fund management and investment companies and 208 investment funds with a total of CHF 26.6 billion in assets under management. There were 48 licensed asset managers in Liechtenstein as of the end of 2006 ( 58 at the date of the focused review), managing an estimated CHF 11.2 billion.

\section{Description of regulatory structure and practices}

36. Responsibility for oversight of banks, investment undertakings, and asset managers rests with the FMA, which has full authority under the Financial Markets Authority Act (FMA Act) to grant licensing applications, review prospectuses and disclosure documents, and carry out supervision of all licensed entities. The FMA also has the ability to impose fines and withdraw licenses. In a change from 2002, licenses are no longer granted by the government, nor does the government have a role in the withdrawal of licenses or imposition of fines. The public prosecutor is responsible for enforcement activity where there is an allegation that a crime has been committed or where the penalty sought includes imprisonment. The FMA has a statutory obligation to inform the public prosecutor if it suspects a crime has been committed.

\footnotetext{
${ }^{6}$ The new legislation provided some limited grandfathering of individuals who were licensed under the Trustee Act on the coming into force of the Asset Management Act. Where the individuals had been acting as an asset manager, article 65 of the legislation provides that their experience is recognized for the purposes of the general manager fit and proper tests set out in the Act. Also, those persons are permitted to be general managers of both an asset management company and a trustee company, although dual licensing is otherwise not contemplated.

${ }^{7}$ One additional bank is in the process of voluntary liquidation.
} 
37. The FMA is obliged to give reasons for its decisions and, generally, these can be appealed to the FMA Complaints Commission, which has been established as an independent tribunal under the FMA Act. Decisions of that body may be appealed to the Superior Administrative Court. The government is not involved in the appeal process.

38. Relevant laws governing securities market activities include the Banking Act, the Investment Undertakings Act, the Asset Management Act, and the Law on Prospectuses, as well as subordinate legislation under each law. The FMA also issues binding rules and administrative guidelines. As a member of the EEA, Liechtenstein is obliged to implement the EU Directives. It has recently implemented the UCITS III Directive and the Market Abuse Directive. It is in the process of implementing the Markets in Financial Instruments Directive (MiFID) and the Capital Requirement Directive (implementation of Basel II).

39. The Liechtenstein system is a "dual" system of oversight, which means that it relies on the use of external auditors to supervise regulated entities. These auditors are accounting and auditing firms that carry out both the regular annual financial audit of a company and a separate regulatory audit reporting to the FMA on the regulated firm's compliance with relevant legal requirements. Auditing as a profession is a licensable activity in Liechtenstein. Where the firm to be audited is a regulated financial firm (bank, investment undertaking, or asset manager), both the audit firm and the individual auditor partner responsible for the audit are subject to additional requirements regarding relevant experience and resources.

40. Since the previous assessment, the FMA has significantly increased its staff resources in the area of banking and securities supervision. There are 11 professional staff: six professionals (with one additional vacancy) devoted to banking supervision and six professionals in securities supervision. ${ }^{8}$ Two more expert staff are soon to be added in the banking supervision area. The qualifications and training of this staff are notably improved since the previous mission. They have performed on-site reviews of both banks and investment undertakings in the past year and perform detailed reviews of the regulatory audit reports received from the auditors. It was clear from our discussions with industry members and associations that these reviews by the FMA staff were both detailed and informed. Further, the industry members respect the FMA and its staff.

41. All of the industry associations with whom the mission met (the Bankers Association, the Funds Association, the Auditors Association, and the Asset Managers Association) appear to be very professional and quite proactive in their approach to regulation. They are actively involved in the process of formulation of policies by the FMA and the development of guidance for their members. The relationship with the FMA is

\footnotetext{
${ }^{8}$ The department also has several recent university graduates in law or economics, who are trainees at present.
} 
constructive and open, with all parties stressing their common concern to protect and promote the reputation of the marketplace as a whole.

\section{Recommendations of the 2002 Assessment and Update}

42. The 2002 Assessment found the securities regulatory regime in Liechtenstein to be largely in compliance with the IOSCO Objectives and Principles of Securities Regulation. There were some areas, however, where implementation was deemed to be incomplete. The mission made a series of recommendations to ensure full implementation. The description below provides a brief reference to these recommendations and then a reassessment of the compliance with those specific principles that were assessed as being less than broadly implemented during the 2002 Assessment.

\section{B. Main Findings}

43. Of the IOSCO Principles that were relevant to Liechtenstein during the previous review, seven were assessed as being partially implemented. Two arose from the principles relating to the regulator, one from the principles for self-regulation, two under the enforcement principles, and two regarding the market intermediary principles. Generally, the sources of most of the deficiencies were the structure and limited authority of the regulator (the regulator at the time was part of the government), its lack of resources and the fact that asset management activities carried on by trustees were not subject to supervision by the regulator.

44. The seven IOSCO Principles were reassessed in accordance with the criteria set out in the Assessment Methodology, taking into account the particular context of the Liechtenstein market. A summary of findings and recommendations is below, followed by a detailed table enumerating each Principle that was reassessed.

45. The Assessment Methodology establishes benchmarks for assessing the level of implementation of each Principle. A Principle will be considered to be fully implemented whenever all assessment criteria (as specified in the benchmarks) are generally met without any significant deficiencies. A Principle will be considered to be broadly implemented whenever a jurisdiction's inability to provide affirmative responses to the assessment questions are limited to specific instances and, in the assessor's judgment of the assessor, such exceptions do not substantially affect the overall adequacy of the regulation that the Principle is intended to address. A Principle will be considered to be partly implemented whenever the assessment criteria specified under the Partly Implemented benchmark for that Principle are generally met without any significant deficiencies. Not implemented means major shortcomings have been found in adhering to the assessment criteria as specified. A Principle is not applicable whenever it does not apply given the circumstances of the assessed jurisdiction. 


\section{Principle-by-principle focused review}

\section{Regulator (Principles 1-5)}

46. The 2002 Assessment recommended that the regulator's mandate should be set out more clearly in one place in the law, and both its independence and authority should be enhanced. The status of the agency was somewhat unclear at law and its authority to act was both vague and limited. The regulator was not an independent agency of the government and its powers were distributed across the relevant laws. It lacked clear authority to grant or withdraw licenses or to levy sanctions against regulated entities without approval from government. The assessment recommended that the regulator be given express authority over licensing, supervision, and the imposition of sanctions against all types of regulated entities without the government's involvement of the government. The assessment also noted that the regulator urgently needed additional experienced staff, so that appropriate supervision could take place. Greater transparency for the regulator's work, including the development of a website, was recommended to increase the public understanding of the regulator's functions and to create a more accountable regulatory process.

47. Principle 2 - Operationally independent and accountable regulator - The FMA is an independent agency formed under the FMA Act, with full authority to license and regulate financial services providers in the jurisdiction, thereby addressing the weaknesses identified. The FMA is accountable to parliament directly through an annual audit and reporting process and the annual report is publicly available on the FMA's website. The consultation process for formulation of new laws, ordinances and guidance is open and the FMA's relationship with the industry is constructive.

48. Principle 3 - Adequate regulatory powers and resources to perform functionsThe FMA has a full range of regulatory powers and its resources are adequate to carry out its current level of activities. The FMA Act and the individual financial services acts administered by the FMA have been amended to give the FMA clear power to license, supervise, and take appropriate enforcement action against banks, investment undertakings, and asset managers. In particular, it has express authority over asset management activities carried on outside banks and insurance companies. It may make legally binding rules. Its resources and funding are stable and currently are reasonably able to support its present level of activities with respect to securities markets participants. Additional funding may be required if demands from EU directives and other initiatives increase. The staff is highly educated and continuous training is a priority. All staff has gained experience since the 2002 Assessment and the many of the added staff have direct experience in relevant industries.

\section{Self-regulatory organizations (Principles 6-7)}

49. The 2002 Assessment recommended that the regulator have a formal role in supervision of the asset management related activities of the Trustees Association. The 
regulatory system in Liechtenstein incorporated the activities of industry associations, which provided a complement to the stretched resources of the regulator. The Trustees Association acted as a self-regulatory body as membership in the association and compliance with its code of conduct was mandatory. The regulator had no authority to supervise the trustees' asset management activities or the Trustee Association directly.

50. Principle 7 - Proper supervision of self-regulatory organizations - With the advent of the Asset Management Act, the FMA has full authority to license, supervise on an on-going basis and take enforcement action against assets managers. The Trustee Association no longer acts as a self-regulatory organization. Membership in the Auditors Association is mandatory for auditors licensed by the FMA, but the Association does not perform self-regulatory functions. Membership in the Independent Asset Managers Association, the Bankers Association, and the Funds Association are voluntary. All the industry associations are active participants in the formulation of relevant regulation and in the implementation of EU directives. While the contribution of the industry associations is important, the FMA must be vigilant in maintaining resources and sufficient experience sufficient to benefit from the associations' input to the policy-making process, but not be dominated by it.

Inspections, Investigations and Enforcement (Principles 8-10)

51. The 2002 Assessment noted that the regulator needed to be given specific authority to supervise the asset management activities carried on by trustees and additional resources to make credible use of the inspection system that utilizes third party auditors. The dual system of inspection should be extended to asset management activities carried on by trustees. Further, the regulator needed additional experienced and trained staff to be able to give the auditors clear and detailed instructions on what must be reviewed, analyze the inspection results and take appropriate action.

\section{Principle 8-Comprehensive regulatory inspection and enforcement powers-} The FMA has full inspection and enforcement powers over banks, investment undertakings and asset managers. Under the dual system, regular inspections of all of these entities are conducted by the appointed external auditor, using guidance provided by the FMA. The FMA has also conducted direct on-site reviews of banks and investment undertakings, either alone, or accompanying the regular auditor. It also has the authority to commission a third party audit of a regulated firm.

53. Principle 10 - Effective use of inspection and enforcement powers-The inspection and enforcement powers of the FMA are used effectively for banks and investment undertakings. The full implementation of the Asset Management Act is at an early stage, and so there is very little experience in that area. However, given that the intention is to build on the expertise and processes in place for the other sectors, it is reasonable to expect a similar level of effectiveness here. 


\section{Information Sharing and Cooperation (Principles 11-13)}

54. The 2002 Assessment viewed the practices in the jurisdiction as broadly implementing these Principles, but recommended that the regulator enhance its practices of sharing information with foreign authorities by entering into informationsharing arrangements with key jurisdictions and by designating a person to be responsible for handling requests. The regulator had the ability to share information with all domestic counterparts and did so in practice. Both the laws on banking and investment undertakings granted the regulator the ability to share information with foreign regulators under certain conditions. The regulator's interpretation of the scope of its authority to share client- related information was upheld by a court decision. The gap in the regulator's authority over trustees, which hampered its ability to share non-public information about asset management carried on by the trustees, should be closed.

55. As the 2002 Assessment found these Principles broadly implemented, no express reassessment was performed. The FMA has the ability to share any information with domestic counterparts and institution- specific information with foreign regulatory authorities, and does so in practice. The laws governing banks, investment undertakings, and asset management give the FMA the ability to share institution-related information on an entity licensed by the FMA with foreign regulators (within or outside the EEA), which that the foreign authority needs to carry out its supervisory responsibilities, subject to requirements to hold the information confidential and not disclose without the express consent of the FMA.

56. The process for sharing client- specific information has several steps, but apparently works comparatively efficiently in practice. The FMA's ability of the FMA to obtain client- related information from its regulated firms is unfettered. Its ability to share client- related information with competent foreign authorities is subject to a process, common across the legislation administered by the FMA, whereby the FMA must issue a formal order to the regulated firm. This order may be appealed within 14 days to the FMA Complaints Commission, an independent tribunal established under the FMA Act, and the decision of that body may be appealed to the Superior Administrative Court.

\section{A 2003 decision of the Superior Administrative Court confirmed the regulator} had the ability to share client- specific information with foreign regulators and set down the principles that had to be met for such disclosure. Further, use of institution or clientrelated information for judicial or administrative enforcement proceedings, even if this entails public disclosure, is now specifically permitted under article 36 of the Banking Act.

58. The Market Abuse Act that entered into force on February 1, 2007 has introduced further refinements to this regime in the context of requests for client information regarding these types of offences. The Act still requires the FMA to issue an order to the regulated entity regarding the proposed information sharing, but only one appeal 
is available directly to the Superior Administrative Court. Further, the statute expressly requires the appeal to be conducted "rapidly." The only statutory grounds for refusing requests are those permitted under the EU directive, and which appear in the equivalent legislation of other EU countries. Liechtenstein goes one step farther than required by the directive and extends this statutory right to competent authorities in non-EEA member states. The only additional conditions that must be fulfilled by these third- country authorities is that the information must only be used for market- abuse matters and must be given equivalent confidentiality to that applied by the FMA, but it may be disclosed as required for a public prosecution of a market- abuse offence. The information may be passed to a third-party regulator in the foreign jurisdiction for that purpose without the specific prior permission of the FMA. All in all, the Liechtenstein regime for sharing information, including the right to appeal, is fully in line with the current IOSCO standards, in particular, the IOSCO MMoU.

59. In order to enhance consistency and efficiency, the FMA is discussing entering into information-sharing arrangements with the Swiss and Austrian authorities and has designated personnel to handle all information requests. The FMA has the power to enter into information-sharing agreements with foreign counterparts, but is not yet a party to an agreement. The lack of formal agreement is not necessarily an impediment to sharing information; but it can be helpful, as then each request does not have to be evaluated individually.

\section{Market Intermediaries (Principles 21-24)}

60. The 2002 Assessment recommended that asset managers should be licensed separately from trustees and that they be actively supervised by the regulator through on-site and off-site examinations. The assessment also noted the need for more detailed rules governing account documentation, representations made to clients, disclosure to clients (both risk and conflicts of interest), rules regarding related- party transactions, and employee conduct.

\section{Principle 21 - Minimum entry standards for market intermediaries-There are} appropriate minimum entry standards for banks and asset managers. There are two kinds of market intermediary in Liechtenstein: banks and asset managers. Banks carry out portfolio management (both discretionary and non-discretionary), distribution of their own and third- party collective investments, execute securities trades for clients, and act as custodians of customer assets. Asset managers carry on discretionary and non-discretionary portfolio management, investment advice and provide research and analysis. Both actions are subject to extensive minimum entry standards, including fit- and proper- assessment and minimum capital requirements. Authorized firms are listed on the FMA's website. The authorities should consider supplementing this disclosure by including the names of the authorized personnel. Further, there should be an affirmative obligation on the part of an asset manager to give prompt notice to the FMA, if it becomes undercapitalized. Priority should be given to full implementation of the Asset Management Act. 


\section{Principle 23-Minimum standards for investor protection and risk}

\section{management-both banks and asset managers are subject to requirements geared to} ensuring investor protection and prudent risk management. The internal control and risk management guidance applicable to banks is extensive. The requirements for asset managers are more general, which is reasonable, given that asset managers have no access to client assets. Both types of regulated firms are subject to MiFID, which that mandates extensive know your client, suitability, and disclosure — both on investment risks and costs — client account and reporting requirements, etc. and the like. The necessary provisions have been incorporated into the relevant statutes and the process of full implementation in the ordinances and guidance is ongoing. The FMA should ensure the guidance provided to external auditors regarding the scope of the regulatory audit of banks and asset managers includes detailed reviews of these provisions when they come into force in November 2007.

\section{Principle-by-Principle Review}

\section{Table 2.1. Focused Review of Certain IOSCO Principles}

\begin{tabular}{|c|c|}
\hline \multicolumn{2}{|r|}{ Principles Relating to the Regulator } \\
\hline Principle 2. & $\begin{array}{l}\text { The regulator should be operationally independent and accountable in the exercise of its } \\
\text { functions and powers. }\end{array}$ \\
\hline Description & $\begin{array}{l}\text { The FMA is an independent agency, established by the Financial Market Authority Act and is } \\
\text { not part of the government administration. It operates independently from the political process } \\
\text { and reports to parliament as a whole, rather than to the government. The FMA consists of a } \\
\text { Board, the General Management and the Audit Office. The individuals appointed are } \\
\text { independent of the government and the minimum qualifications and mechanisms for } \\
\text { appointment, term of office and reasons for removal are set out in the legislation. The majority } \\
\text { of the Board members (including the Chairman and Deputy Chairman) must be independent of } \\
\text { all regulated entities. Board members, general management, and staff are protected from legal } \\
\text { action in the good faith execution of their duties under the Law on Official Liability. } \\
\text { The FMA's budget consists of funds contributed by the government and fees on industry } \\
\text { members. In } 2007, \text { the split was } 54.3 \text { percent from the government and } 45.7 \text { percent from fees. } \\
\text { The budget provides a stable source of funding and the resources provided to the FMA have } \\
\text { been significantly increased over those in place during the } 2002 \text { Assessment. Management also } \\
\text { indicated that where additional resources have been needed, the necessary budgetary increase } \\
\text { was made available. } \\
\text { The FMA Act states that the agency is not bound by any instructions and the government does } \\
\text { not appear to interfere in the day-to-day operations of the FMA. } \\
\text { The FMA works cooperatively and constructively with the industry in developing its approach } \\
\text { to policy and implementation of EU directives. The level of interaction appears to achieve a } \\
\text { good balance between making use of industry expertise and maintaining the necessary } \\
\text { regulatory objectivity. } \\
\text { The FMA is accountable for its activities to parliament. The regulator prepares an annual report } \\
\text { of its activities and this report is posted on the FMA's website. The website also contains the } \\
\text { laws, ordinances, and guidelines administered by the FMA, along with lists of all authorized } \\
\text { firms. Much of this information is also available on the website in English. In addition, the } \\
\text { industry associations and through extensive consultations on new initiatives. }\end{array}$ \\
\hline
\end{tabular}




\begin{tabular}{|c|c|}
\hline & $\begin{array}{l}\text { Decisions taken by the FMA are made in writing and generally are subject to appeal. Affected } \\
\text { parties are afforded an opportunity to make representations, usually in writing or through face } \\
\text { face-to- face meetings. In most cases, the first appeal is to the FMA Complaints Commission } \\
\text { established under the FMA Act. Appeals from those decisions go to the Liechtenstein Superior } \\
\text { Administrative Court, which that is the final level of appeal. The period for filing an appeal in } \\
\text { both cases is } 14 \text { days. In practice, the courts deal with appeals in a reasonably expeditious } \\
\text { manner. } \\
\text { Extensive confidentiality obligations apply to anyone acting for the FMA, law enforcement } \\
\text { personnel, the public prosecutor, and to all market participants. }\end{array}$ \\
\hline Assessment & Fully implemented \\
\hline Comments & $\begin{array}{l}\text { This principle was rated "partly implemented" during the } 2002 \text { assessment on the basis that the } \\
\text { regulator's authority to oversee securities activities, including powers and independence were } \\
\text { not clearly provide for in the law. }\end{array}$ \\
\hline Principle 3. & $\begin{array}{l}\text { The regulator should have adequate powers, proper resources and the capacity to perform its } \\
\text { functions and exercise its powers. }\end{array}$ \\
\hline Description & $\begin{array}{l}\text { The FMA has been granted licensing and supervision power over banks, asset managers and } \\
\text { investment undertakings, which includes the right to obtain information, request reports, and } \\
\text { inspect. It also has the ability to withdraw licenses and levy penalties on regulated entities. The } \\
\text { FMA has the ability to share supervisory information with domestic and foreign counterparts, } \\
\text { subject to conditions that include ones relating to confidentiality at the receiving body. } \\
\text { Under the FMA Act, the FMA has the authority to issue legally binding and enforceable rules } \\
\text { and may enforce those requirements itself. } \\
\text { The FMA has a staff of } 11 \text { professionals in the Banking and Securities Supervision Department } \\
\text { and the budgetary process appears to accommodate the need for additional resources as the } \\
\text { demands of regulation grow. For example, the FMA's budget recently was increased to permit } \\
\text { the hiring of an expert to assist in the implementation of the EU Capital Requirement Directive. } \\
\text { The FMA has recruited staff from Austria, Liechtenstein, and Switzerland, Austria and } \\
\text { Liechtenstein. The overall level of experience and qualifications of the staff are quite high and } \\
\text { the agency actively promotes additional training. The Staff is very dedicated and professional, } \\
\text { and turnover has been low since the FMA was formed. } \\
\text { The FMA's budget provides a stable source of funding and the resources provided to the FMA } \\
\text { have been significantly increased over those in place during the } 2002 \text { Assessment. Management } \\
\text { also indicated that where additional resources have been needed, the necessary budgetary } \\
\text { increase was made available. They have discretion to allocate resources as needed. }\end{array}$ \\
\hline Assessment & Fully implemented \\
\hline Comments & $\begin{array}{l}\text { For the } 2007 \text { focused review, the current resources seem to be adequate to carry out the current } \\
\text { level of activities undertaken by the FMA. However, as the implementation demands of } \\
\text { proliferating EU directives increase, additional staff may be needed. Full implementation of the } \\
\text { relatively new Asset Management Act also may put pressure on the existing level of resources. } \\
\text { Further, if the FMA increases the number of on-site inspections it performs itself-not using } \\
\text { external auditors - the staffing may have to be augmented. } \\
\text { This principle was rated "partly implemented" during the } 2002 \text { assessment on the basis that } \\
\text { resources were insufficient for banking supervision and investment undertakings supervision. }\end{array}$ \\
\hline \multicolumn{2}{|r|}{ Principles of Self-Regulation } \\
\hline Principle 7. & $\begin{array}{l}\text { SROs should be subject to the oversight of the regulator and should observe standards of } \\
\text { fairness and confidentiality when exercising powers and delegated responsibilities. }\end{array}$ \\
\hline Description & $\begin{array}{l}\text { With the changes to the regulatory structure and powers of the FMA and the advent of the Asset } \\
\text { Management Act, there are no self-regulatory organizations in Liechtenstein. The Trustees } \\
\text { Association no longer performs that role with respect to market intermediaries in the } \\
\text { jurisdiction. }\end{array}$ \\
\hline
\end{tabular}




\begin{tabular}{|c|c|}
\hline Assessment & Not applicable \\
\hline Comments & $\begin{array}{l}\text { For the current focused review, while the contribution of the industry associations to policy } \\
\text { development is important, the FMA must be vigilant in maintaining resources and experience } \\
\text { that is sufficient to benefit from the associations' input to the policy-making process, but not be } \\
\text { dominated by it. } \\
\text { This principle was rated "partly implemented" during the } 2002 \text { assessment on the basis that the } \\
\text { trustee's association as an SRO was not subject to supervision or licensing. The FMA has } \\
\text { assumed the oversight responsibilities directly. }\end{array}$ \\
\hline & Principles for the Enforcement of Securities Regulation \\
\hline Principle 8. & The regulator should have comprehensive inspection, investigation, and surveillance powers. \\
\hline Description & 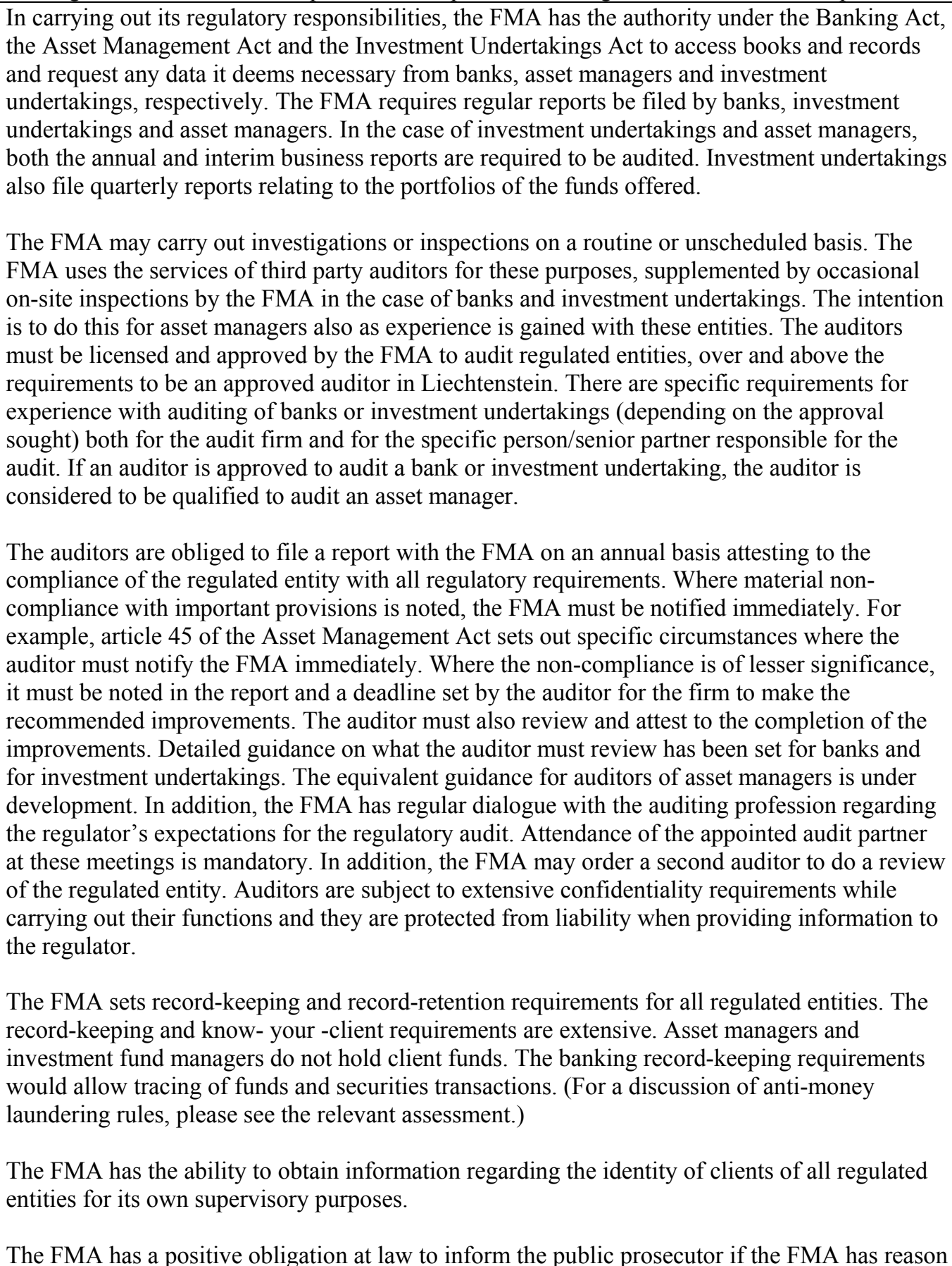 \\
\hline
\end{tabular}




\begin{tabular}{|c|c|}
\hline & $\begin{array}{l}\text { to suspect that a crime has taken place. The public prosecutor has the authority to request } \\
\text { documents or oral testimony in the case of an official investigation by the court. } \\
\text { The FMA has been granted specific authority under the banking, investment undertaking and } \\
\text { asset management legislation to take enforcement action against market participants where a } \\
\text { breach of the requirements has taken place. For example, under Article } 62 \text { of the Asset } \\
\text { Management Act, the FMA may impose fines of up to CHF } 100,000 \text { for specified breaches of } \\
\text { that law. The FMA has a ladder of compliance in place containing escalating responses to non- } \\
\text { compliance by a regulated entity, ranging from issuing a compliance order through to } \\
\text { withdrawal of the entity's license. }\end{array}$ \\
\hline Assessment & Fully implemented \\
\hline Comments & $\begin{array}{l}\text { This principle was rated "partly implemented" during the } 2002 \text { assessment on the basis that } \\
\text { there was no supervisor with authority to inspect trustees acting as asset manager. In the current } \\
\text { focused review, the FMA has been granted this authority. }\end{array}$ \\
\hline Principle 10. & $\begin{array}{l}\text { The regulatory system should ensure an effective and credible use of inspection, investigation, } \\
\text { surveillance and enforcement powers and implementation of an effective compliance program. }\end{array}$ \\
\hline Description & 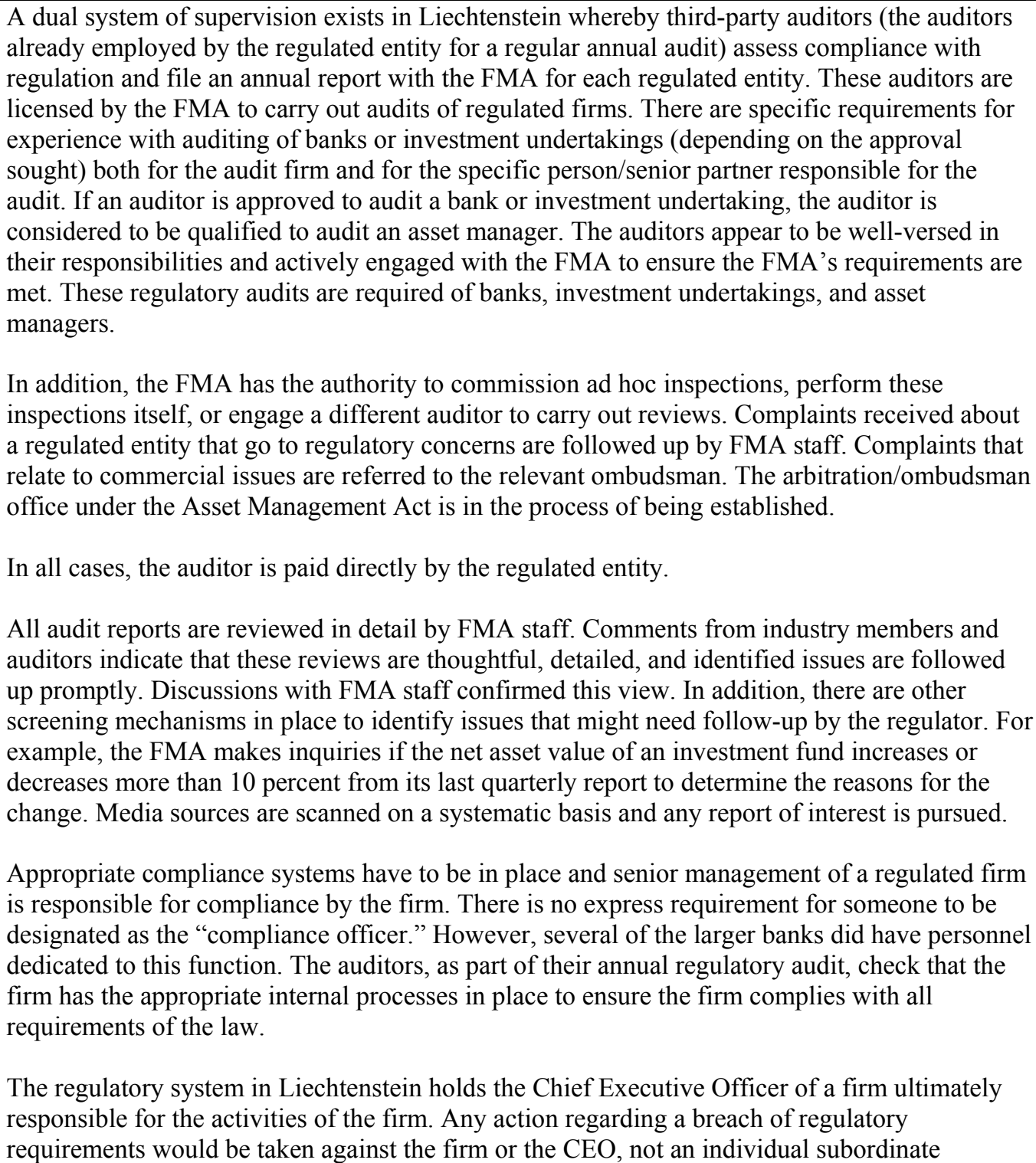 \\
\hline
\end{tabular}




\begin{tabular}{|c|c|}
\hline & $\begin{array}{l}\text { employee. The statutory liability of these persons is joint and several with the company for } \\
\text { administrative or criminal fines. The one exception would be if the actions of the employee } \\
\text { amounted to a criminal act, in which case, the public prosecutor would charge that individual } \\
\text { and the matter would be pursued in the Courts of Justice. } \\
\text { The FMA has been granted specific authority under the banking, investment undertaking, and } \\
\text { asset management legislation to take enforcement action against market participants where a } \\
\text { breach of the requirements has taken place. The FMA has a ladder of compliance in place } \\
\text { containing escalating responses to non-compliance by a regulated entity, ranging from issuing a } \\
\text { compliance order to withdrawal of the entity's license. } \\
\text { Overall, the enforcement system appears to be effective to ensure an acceptable level of } \\
\text { compliance by regulated firms. All interested parties-the FMA, the government, industry } \\
\text { members, industry associations, and the hereditary prince-stated that the most valuable asset } \\
\text { of the jurisdiction and the financial services industry was its high reputation, and that a blemish } \\
\text { on that reputation was of concern to all. Several industry members noted that if they observed } \\
\text { less than stellar behaviour by other participants, they would try to exercise moral suasion to } \\
\text { rectify the behaviour, and, if that didn't work, they would report the matter to the regulator. }\end{array}$ \\
\hline Assessment & Fully implemented \\
\hline Comments & $\begin{array}{l}\text { As noted in the comment to Principle 7, the current resources seem to be adequate to carry out } \\
\text { the current level of activities undertaken by the FMA. However, as the implementation demands } \\
\text { of proliferating EU directives increase, additional staff may be needed. } \\
\text { Priority should be given to development of the appropriate guidance for auditors in performing } \\
\text { the regulatory audit of asset managers. } \\
\text { With the advent of MiFID, the regulatory audits of banks, investment undertakings, and asset } \\
\text { managers should include a review of the compliance of these entities with the disclosure and } \\
\text { sales conduct rules imposed under that directive. } \\
\text { This principle was rated "partly implemented" during the } 2002 \text { assessment on the basis that the } \\
\text { regulator lacked resources to evaluate the results of the audits that were carried out for the } \\
\text { purpose of supervision. }\end{array}$ \\
\hline \multicolumn{2}{|r|}{ Principles for Market Intermediaries } \\
\hline Principle 21 & Regulation should provide for minimum entry standards for market intermediaries. \\
\hline Description & $\begin{array}{l}\text { There are two kinds of market intermediary in Liechtenstein: banks and asset managers. Banks } \\
\text { carry out portfolio management (both discretionary and non-discretionary), distribution of their } \\
\text { own and third party collective investments, execute securities trades for clients and act as } \\
\text { custodians of customer assets. Banks are subject to minimum entry standards including fit and } \\
\text { proper assessment of owners, directors and officers, minimum capital, internal control and } \\
\text { capacity requirements. (See the Basel Core Principles focused review.) } \\
\text { Asset managers carrying on discretionary portfolio management, providing investment advice, } \\
\text { receiving and transmitting orders for transactions in financial instruments or providing } \\
\text { investment research and analysis are required to be licensed by the FMA under the Asset } \\
\text { Management Act. Certain entities, such as banks, are permitted to carry on these activities } \\
\text { without separate authorization under this legislation }{ }^{9} \text {. All customer cash and assets must be held } \\
\text { in a depository/ custodian bank, and the manager may not withdraw either cash or assets. All } \\
\text { trades are conducted through the depository. The Asset Management Act became effective on } \\
\text { January } 1,2006 \text { and still is in the process of full implementation. }\end{array}$ \\
\hline
\end{tabular}

\footnotetext{
${ }^{9}$ The exceptions to the licensing requirements are the usual ones: banks, insurance companies, central banks, government bodies, and entities managing assets only for related entities. See article paragraph 2 for a complete list.
} 


\begin{abstract}
Asset managers are subject to a licensing process that involves a complete fit- and- proper review of the firm, its principals, and any person with a qualifying shareholding (over 10\% percent voting equity or other material influence). The initial requirements include delivery of evidence of reasonable business plans, sufficient financial resources, appropriate back- office systems in place, etc. Fit- and- proper assessments include reviews of professional qualifications and reputation, criminal records and bankruptcy history checks, requests for information from foreign regulators, reviews of information available from the internet, and other media sources plus personal interviews.
\end{abstract}

There is a minimum capital requirement that reflects the relatively low risk nature of the business of asset management. This initial capital requirement must be maintained at all times. However, it is not clear that the asset management company has an obligation to notify the FMA immediately if it becomes undercapitalized. In any event, the auditor must attest that the capital requirement was fulfilled continuously throughout the year, so if the regulated firm had been undercapitalized at some point, that fact would be flagged to the FMA as part of the regulatory audit.

The application process involves both reviews of the documents received and face- to- face meetings with the key personnel of the applicant. The minimum standards for licensing of banks and asset managers are clearly set out in the legislation and ordinances. The website of the FMA contains useful checklists and other guidance to applicants on the requirements and process. The initial requirements must continue to be fulfilled throughout the time the firm is authorized.

The FMA has full authority to license banks and asset managers or refuse to issue a license if not completely satisfied that all criteria are met. It has statutory authority to suspend, withdraw, or place conditions on a licensee if the authorization conditions are no longer fulfilled, or some material change in circumstances has occurred. Proposed changes in key management or in substantial shareholdings must be disclosed to the regulator, and they have a right to approve/refuse permission for the proposed change. Notice of other less material changes must be given to the regulator promptly.

The website of the FMA lists authorized firms and sets out their addresses and other contact details. The names of the authorized general managers of these firms are not included. Liechtenstein applies a single licensing regime, which means a regulated firm is entitled to carry on any of the statutory activities permitted in that category. The authorized activities of firms are clearly set out on the website and in the law.

The FMA has full investigation and enforcement powers regarding the activities of banks and asset management firms. See the discussion above under Principles 8 and 10. As the Asset Management Act is still in the process of full implementation, it is too early to state with certainty what level of enforcement will be imposed in practice. However, as the law provides the FMA with the same powers as for the oversight of banks and investment undertakings, and the stated intention of the FMA is to use the techniques as applied to these other segments of the financial services industry, it is reasonable to expect a similar level of enforcement effectiveness.

Both the banks and the asset managers are subject to the conflict of interest, know your client, investment risk disclosure, and other requirements imposed by MiFID. The statutory framework for implementation of MiFID has been incorporated into the statutes ${ }^{10}$ and the detailed requirements are in the process of being finalized.

The Code of Conduct for Asset Managers is in development.

\footnotetext{
${ }^{10}$ For example, see articles 14 to 25 of the Asset Management Act dealing with Investor Protection.
} 


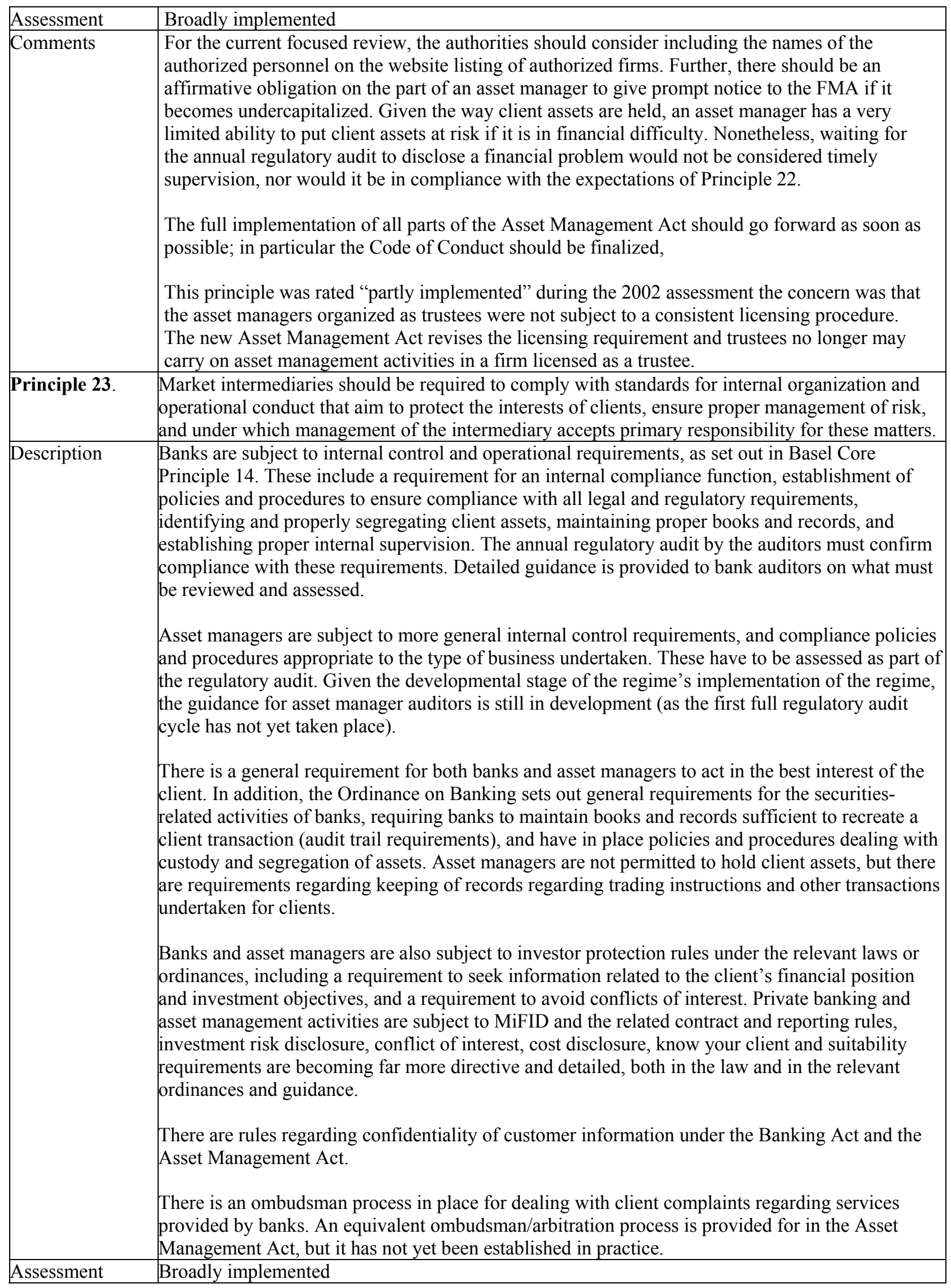




\begin{tabular}{|l|l|}
\hline Comments & $\begin{array}{l}\text { For the current focused review, the FMA should ensure that compliance with the MiFID investor } \\
\text { protection requirements is a specific segment of the regulatory audit performed on asset managers } \\
\text { and banks. Full implementation of the regime governing asset managers should be a priority. }\end{array}$ \\
& $\begin{array}{l}\text { This principle was rated "partly implemented" during the } 2002 \text { assessment because of a lack of } \\
\text { resources and therefore inability to adequately review and monitor the audit process, which is the } \\
\text { chief supervision tool. }\end{array}$ \\
\hline
\end{tabular}

Table 2.2 Summary of Implementation of the IOSCO Objectives and Principles

\begin{tabular}{|l|c|c|}
\hline \multicolumn{1}{|c|}{$\begin{array}{c}\text { Assessment } \\
\text { Grade }\end{array}$} & Count & List \\
\cline { 2 - 3 } & 4 & P 2, 3, 8, 10 \\
\hline Implemented & 2 & P 21, 23 \\
\hline Broadly Implemented & & \\
\hline Partly Implemented & & \\
\hline Not Implemented & 1 & P 7 \\
\hline Not applicable & 1 & \\
\hline
\end{tabular}

\section{Recommended Actions and Authorities' Response to the Focused Review}

\section{Table 2.3 Action Plan to Improve Implementation of the IOSCO Principles}

\begin{tabular}{|c|c|}
\hline Reference Principle & Recommended Action \\
\hline Principles Concerning the Regulator (P1 to P5) & $\begin{array}{l}\text { Current resources may have to be supplemented if more direct } \\
\text { audits by the FMA are carried out or if the demands of full } \\
\text { implementation of EU directives and the Asset Management } \\
\text { Act increase. }\end{array}$ \\
\hline $\begin{array}{l}\text { Principles for the Enforcement of Securities } \\
\text { Regulation (P8 to P10) }\end{array}$ & $\begin{array}{l}\text { Priority should be given to development of the appropriate } \\
\text { guidance for auditors in performing the regulatory audits of } \\
\text { asset managers }\end{array}$ \\
\hline $\begin{array}{l}\text { Principles for Market Intermediaries } \\
\text { (P21 to P24) }\end{array}$ & $\begin{array}{l}\text { The authorities should consider including the names of the } \\
\text { authorized personnel on the website listing of authorized } \\
\text { firms. } \\
\text { There should be an affirmative obligation on the part of an } \\
\text { asset manager to give prompt notice to the FMA if it becomes } \\
\text { undercapitalized. } \\
\text { The full implementation of all parts of the Asset Management } \\
\text { Act should go forward as soon as possible; in particular the } \\
\text { Code of Conduct should be finalized., } \\
\text { The FMA should ensure that compliance with the MiFID } \\
\text { investor protection requirements is a specific segment of the } \\
\text { regulatory audit performed on both asset managers and banks. }\end{array}$ \\
\hline
\end{tabular}




\section{Table 2.4 Status of Recommendations from the 2002 Action Plan: IOSCO Principles}

\begin{tabular}{|c|c|}
\hline $\begin{array}{l}\text { Reference Principle \& } 2002 \text { Assessment } \\
\text { Recommended Actions }\end{array}$ & Actions Taken \\
\hline $\begin{array}{l}\text { Principles Concerning the Regulator (P1 to } \\
\text { P5) } \\
\text { Increased staffing resources are urgently } \\
\text { needed. }\end{array}$ & $\begin{array}{l}\text { Staff in banking and securities supervision increased } \\
\text { substantially. }\end{array}$ \\
\hline $\begin{array}{l}\text { Training of staff should be a priority; consider } \\
\text { working with other jurisdictions }\end{array}$ & $\begin{array}{l}\text { New staff hired with direct experience of industries } \\
\text { regulated; additional training of staff undertaken; several } \\
\text { more years experience in supervision for staff since last } \\
\text { review. }\end{array}$ \\
\hline The FSA mandate should be clearer in law. & $\begin{array}{l}\text { The FMA Act clearly sets out, in one place, the overall } \\
\text { mandate of the regulator. }\end{array}$ \\
\hline $\begin{array}{l}\text { The FSA should have authority to grant, } \\
\text { refuse, and withdraw licenses for banks, } \\
\text { investment undertakings, and asset managers. }\end{array}$ & $\begin{array}{l}\text { The FMA, via amendments to the relevant banking and } \\
\text { investment undertakings laws and the introduction of the } \\
\text { Asset Management Act, has express authority to grant, } \\
\text { refuse, and withdraw licenses for banks, investment } \\
\text { undertakings, and asset managers. }\end{array}$ \\
\hline $\begin{array}{l}\text { Criteria for selection and dismissal of the FSA } \\
\text { head should be set out in a manner that is } \\
\text { transparent and legally binding on the } \\
\text { government. }\end{array}$ & $\begin{array}{l}\text { The FMA Act sets out objective criteria for the selection } \\
\text { and termination of Board members of the FMA and for } \\
\text { general management, including the CEO; Board members } \\
\text { are selected by parliament; general management is selected } \\
\text { by the Board. }\end{array}$ \\
\hline $\begin{array}{l}\text { Greater transparency through a website should } \\
\text { be introduced. }\end{array}$ & $\begin{array}{l}\text { The FMA website contains the annual report, all laws, } \\
\text { ordinances and guidelines, a complete list of all authorized } \\
\text { firms, checklists for applicants and other useful information. } \\
\text { Many of these documents are also available in English }\end{array}$ \\
\hline $\begin{array}{l}\text { The FSA should have the authority to make } \\
\text { legally binding rules. }\end{array}$ & $\begin{array}{l}\text { The FMA Act gives the FMA express authority to make } \\
\text { legally binding rules. }\end{array}$ \\
\hline \multicolumn{2}{|l|}{$\begin{array}{l}\text { Principles for the Enforcement of Securities } \\
\text { Regulation (P8 to P10) }\end{array}$} \\
\hline $\begin{array}{l}\text { FSA should have the ability to withdraw } \\
\text { licenses and levy fines. }\end{array}$ & $\begin{array}{l}\text { The FMA has the full authority to withdraw or condition } \\
\text { licenses, levy fines, and take other enforcement actions } \\
\text { against banks, investment undertakings and asset managers. }\end{array}$ \\
\hline $\begin{array}{l}\text { FSA should have authority to inspect and } \\
\text { supervise trustees. }\end{array}$ & $\begin{array}{l}\text { The new Asset Management Act requires asset managers to } \\
\text { be licensed as such by the FMA and gives the FMA the } \\
\text { authority to license, inspect, and take enforcement action } \\
\text { against these entities. Trustees no longer may carry on asset } \\
\text { management activities in a firm licensed as a trustee. }\end{array}$ \\
\hline $\begin{array}{l}\text { Principles for Cooperation in Regulation } \\
\text { (P11 to P13) }\end{array}$ & \multirow{2}{*}{$\begin{array}{l}\text { The Banking, Investment Undertakings and Asset } \\
\text { Management Acts contain express provisions setting out the } \\
\text { authority of the FMA to share information with others. }\end{array}$} \\
\hline $\begin{array}{l}\text { The FSA should adopt new policies and } \\
\text { procedures to implement their authority to } \\
\text { share client account information. }\end{array}$ & \\
\hline $\begin{array}{l}\text { FSA should enter into information sharing } \\
\text { arrangements with key counterparts, } \\
\text { specifically the Swiss. }\end{array}$ & $\begin{array}{l}\text { Information- sharing agreements are under discussion with } \\
\text { the Swiss Banking Commission and with the Austrian } \\
\text { Financial Market Authority. }\end{array}$ \\
\hline
\end{tabular}




\begin{tabular}{|c|c|}
\hline $\begin{array}{c}\text { Reference Principle \& } 2002 \text { Assessment } \\
\text { Recommended Actions }\end{array}$ & Actions Taken \\
\hline $\begin{array}{l}\text { Principles for Collective Investment } \\
\text { Schemes (P17 to P20) } \\
\text { FSA should develop more detailed net-asset- } \\
\text { valuation rules. }\end{array}$ & $\begin{array}{l}\text { Improvements to net asset value rules and the valuation } \\
\text { rules that apply to illiquid securities are in the planning } \\
\text { stages. }\end{array}$ \\
\hline $\begin{array}{l}\text { FSA should develop conflicts of interest rules } \\
\text { for investment undertakings. }\end{array}$ & $\begin{array}{l}\text { A Code of Conduct has been developed and implemented } \\
\text { for investment undertakings. The implementation of MiFID } \\
\text { will supplement the Code. These should be final by the end } \\
\text { of the year. }\end{array}$ \\
\hline $\begin{array}{l}\text { FSA should consider more detailed rules for } \\
\text { duties of custodians. }\end{array}$ & $\begin{array}{l}\text { Additional guidance for custodians was introduced as part } \\
\text { of the implementation of the UCITS III Directive. }\end{array}$ \\
\hline $\begin{array}{l}\text { FSA requires more resources/more } \\
\text { experienced staff for review of audits and } \\
\text { prospectuses. }\end{array}$ & $\begin{array}{l}\text { Additional staff with enhanced experience are available for } \\
\text { review of audit reports and disclosure documents. Detailed } \\
\text { review and follow-up is performed for all audit reports of } \\
\text { investment funds and their managers. }\end{array}$ \\
\hline $\begin{array}{l}\text { Principles for Market Intermediaries } \\
\text { (P21 to P24) } \\
\text { Asset managers organized as trustees should } \\
\text { be subject to a separate licensing procedure, } \\
\text { which sets terms of their ability to carry out } \\
\text { asset management business and makes this } \\
\text { transparent to the public. }\end{array}$ & $\begin{array}{l}\text { The new Asset Management Act requires asset managers to } \\
\text { be licensed as such by the FMA and gives the FMA the } \\
\text { authority to license, inspect, and take enforcement action } \\
\text { against these entities. Trustees no longer may carry on asset } \\
\text { management activities in a firm licensed as a trustee. }\end{array}$ \\
\hline $\begin{array}{l}\text { FSA should have licensing-, supervision-, and } \\
\text { rule-making authority regarding asset } \\
\text { managers. }\end{array}$ & $\begin{array}{l}\text { See above. The FMA may make binding rules regarding } \\
\text { asset management. }\end{array}$ \\
\hline $\begin{array}{l}\text { Asset managers should be subject to an annual } \\
\text { FSA audit. }\end{array}$ & $\begin{array}{l}\text { Asset managers are subject to both financial and regulatory } \\
\text { audits, as are banks and investment undertakings. Both sets } \\
\text { of audits are performed by FMA- licensed auditors using the } \\
\text { dual system of supervision. The intention of the FMA is to } \\
\text { do some direct on-site reviews in future, either alone or } \\
\text { accompanying the external auditor. }\end{array}$ \\
\hline $\begin{array}{l}\text { FSA should develop more detailed rules } \\
\text { regarding sales and business conduct of } \\
\text { market intermediaries. }\end{array}$ & $\begin{array}{l}\text { The implementation of MiFID entails the imposition of } \\
\text { extensive investor protection requirements on banks and } \\
\text { asset managers. The laws on banking and asset management } \\
\text { already include certain statutory disclosure and other } \\
\text { requirements consistent with MiFID. Additional guidance } \\
\text { will be introduced before full implementation in } \\
\text { November } 2007 \text {. }\end{array}$ \\
\hline
\end{tabular}

\section{Authorities Response}

The Financial Market Authority Liechtenstein (FMA) is very grateful to the IMF for having carried out an update of the OFC assessment 2002. Seven principles have been reassessed; four of them rated "implemented," two "broadly implemented," and one "not applicable." This reflects the very positive development and progress Liechtenstein has made, in general, 
and the FMA has achieved in particular since its start on 1 January 1, 2005. The necessary action regarding the two principles rated "broadly implemented" has been started.

Since the assessment took place in March/April 2007, some of the recommendations have already been implemented. MiFID was implemented into national law by November 2007 and is fully applicable to banks and asset management companies. The FMA regularly held workshops with auditors of asset management companies to give them proper guidance and developed a model audit report. Thus, many of the current recommendations will be met. 